\title{
Studije
}

Pregledni članak UDK 111.8(045)

1 Thomas Aquinas, sanctus doi: $\underline{10.21464 / f i 39209}$

Primljeno: 21. 1. 2019.

\section{Predrag Milidrag}

Institut društvenih nauka, Kraljice Natalije 45, RS-11000 Beograd pmilidrag@idn.org.rs

\section{Toma Akvinski o transcendentalima u De veritate, $\mathrm{q} .1$, a. 1}

\begin{abstract}
Sažetak
Tekst analizira izvođenje transcendentalnih pojmova Tome Akvinskoga u prvom članku prvog pitanja Raspravljenih pitanja o istini (Questiones disputatae de veritate). Nakon pokazivanja načina na koji je moguće dodavanje biću (ens), detaljno se analiziraju transcendentalni pojmovi res, unum, aliquid, verum $i$ bonum. Pri analizi pojma stvari pokazuje se poseban status bića, naime kao prvotnog, "transcendentalizirajućeg" transcendentala (Cornelio Fabro). U kontekstu verum i bonum, ističe se razlika između istine $i$ dobrog kao transcendentalnih pojmova te istine $i$ dobrog $u$ spoznajnom $i$ etičkom smislu. $U$ zaključku, izdvojena su tri obilježja transcendentala prema stvarnosti (zamjenjivost, identitet $i$ koekstenzivnost $s$ bićem) $i$ tri obilježja prema značenju (uključenost bića, razlikovanje od bića $i$ međusobno razlikovanje te poredak).
\end{abstract}

\section{Ključne riječi}

Toma Akvinski, transcendentali, biće, stvar, jedno, dobro, istinito, drugo, metafizika, skolastika

\section{Uvod}

Iako svi pojmovi izražavaju moduse bitka (jer je sve o čemu mislimo ili govorimo biće neke vrste), većina njih izražava određene vrste bitka (esse). Transcendentali, međutim, kao što su biće, jedno, dobro, istinito izražavaju opće moduse bitka koji pripadaju svakom biću upravo utoliko ukoliko je biće (modus generalis consequens omne ens). ${ }^{1}$ Transcendentali su tako nazvani jer

Usp. De ver., q. 1, a. 1. Djela Anđeoskog doktora bit će citirana na sljedeći način: $S T$

- Summa theologiae, SCG - Summa contra Gentiles, In Sent. - Scriptum super Sententiis magistri Petri Lombardi, In Meta. - In duodecim libros Metaphysicorum Aristotelis ex- positio, In De Trin. - Expositio super librum Boethii De Trinitate, De ver. - Ouaestiones disputatae de veritate, De pot. - Quaestiones disputatae de potentia Dei, DEE - De ente et essentia, Comp. th. - Compendium theologiae, In Periherm. - In Aristotelis li- 
nadilaze, prekoračuju, »uspinju se onkraj« (scendere trans) deset kategorija bitka. No postoje dva načina za transcendiranje kategorija. Jedan je ostaviti ih potpuno iza sebe i utoliko se »uspeti iznad « njih, dok je drugi način biti prisutan u svima njima i pritom » prelaziti preko« njihovih granica. ${ }^{2}$ Posljedično tomu, upravo da bi se razlikovala ta dva smisla, skolastičari modernog doba razlikovali su izraz transcendentno, da bi označili ono što nadilazi kategorije u prvom smislu, i transcendentalno da bi označili drugi smisao. ${ }^{3} \mathrm{U}$ prvom je smislu Bog transcendentan jer ne potpada pod kategorije stvorenog svijeta, u drugom je smislu, primjerice, pojam jednog transcendentalan jer se može naći u svih deset kategorija koje na taj način transcendira. Dakle, Bog nadilazi kategorije zato što nije prisutan ni u jednoj od njih, dok ih transcendentali nadilaze tako što su prisutni u svima njima ${ }^{4}$ te su, dakle, svima njima zajednički. Zato Toma Akvinski transcendentalne pojmove naziva i communissima, ${ }^{5}$ communia ${ }^{6}$ ili transcendentia, ${ }^{7}$ ali i prima na temelju toga što su prvi pojmovi duha. ${ }^{8}$ To su passiones entis koji su, uz zajedničko biće (ens commune), predmet metafizike kao znanosti. ${ }^{9}$

Problem transcendentala dominikanski učitelj detaljnije obrađuje na nekoliko mjesta u svom opusu, ali locus princeps jest prvi članak prvog pitanja Raspravljenih pitanja o istini (Quaestiones disputatae de veritate). Akvinac je o transcendentalima raspravljao i na drugim mjestima, primjerice u dvadeset prvom pitanju Raspravljenih pitanja o istini (čl. 1 i 3) ili u Komentaru Sentencija Petra Lombarda. ${ }^{10}$ Prvi članak prvog pitanja djela De veritate bit će u središtu pozornosti ovog teksta zato što je riječ o najcjelovitijem ${ }^{11}$ i najobimnijem tekstu u kojem se svetac bavi problemom transcendentala, ${ }^{12}$ ali i zato što je to misao »zrelog Tome« $(1256 .-1259.){ }^{13} \mathrm{~S}$ obzirom na ograničenost prostora i temu teksta, neće biti riječi o transcendentalima kao Božjim imenima. ${ }^{14}$

Budući da je istina stvar razuma, Raspravljena pitanja o istini Toma Akvinski započinje izlaganjem o nužnosti toga da se sve razumske operacije svedu na samo-očigledne principe, ne bi li se izbjegao beskonačni regres koji može uništiti spoznaju. Započinje zapažanjem da

»... [t]reba reći da kao što se kod dokazivanja dokažljivih iskaza dokazni postupak mora svesti na neka načela umu samo po sebi poznata, tako isto mora biti i kod istraživanja što je svaka pojedina stvar; inače bi se u oba slučaja išlo u beskraj, pa bi tako sasvim propala znanost i spoznaja stvari. A ono što um najprije poima kao najpoznatije i na što svodi sve pojmove, jest biće, kao što kaže Avicenna na početku svoje Metafizike. ${ }^{15}$

Moramo svesti demonstrabilne propozicije na neke koje su poznate po sebi da bismo imali znanost o stvarima i moramo svesti nedemonstrabilne definicije na neki pojam koji je znan po sebi da bismo imali spoznaju stvari. Znamo da se demonstracija treba svesti na princip neproturječnosti, ${ }^{16}$ ali na što svesti definicije? Akvinac odmah nudi nešto što je po sebi najpoznatije:

»A ono što um najprije poima kao najpoznatije i na što svodi sve pojmove, jest biće. « ${ }^{17}$

Kao što pri demonstraciji zaključak mora biti svodiv na neki prvi princip (ili principe) koji sam po sebi ne zahtijeva opravdanje ( $\mathrm{tj}$. on je per se nota), tako se i u oblikovanju definicija sve mora svesti na nešto prvo što je poznato po sebi. Zapravo, budući da je znanost sačinjena od demonstracija, demonstracije od propozicija, a propozicije od pojmova, zasnivanje svih definicija i pojmova na nečem prvom i per se nota pri istraživanju konstituira temelj za cjelokupnu znanost i spoznaju. ${ }^{18}$ Pozivajući se na Avicenninu Metafiziku, Akvinski potom tvrdi da prva stvar koju razum poima jest biće. Budući da Akvinac započinje svoj odgovor tvrdnjom da su sve stvari u demonstraciji 
svodive na principe koji su per se nota, smisao »prvog « očito je logička ili metafizička prvotnost, a ne vremenska. Drugi dio problema jest pitanje zašto treba prihvatiti biće kao prvu stvar koju razum poima, čak i u opisanom

bros Peri hermeneias et Posteriorum analyticorum expositio, In De hebd. - Expositio libri Boetii De ebdomadibvs, De sub. sep. - Tractatus de substantiis separatis. Ovim putem ujedno zahvaljujem anonimnim recenzentima na korisnim sugestijama. (Rad je pisan u okviru programa istraživanja IDN-a za 2020 koji podržava Ministarstvo prosvete, nauke i tehnološkog razvoja R. Srbije)

2

U tom smislu govorimo da, primjerice, neke vrijednosti transcendiraju kulturu, naciju ili politiku, ne zato što se one ne bi nalazile ni u jednoj kulturi, naciji ili političkom pokretu, nego zato što su zajedničke svima njima.

Usp. Jan A. Aertsen, »The Concept of 'Transcendens' in the Middle Ages: What is Beyond and What is Common«, u: Gerd van Riel i dr. (ur.), Platonic Ideas and Concept Formation in Ancient and Medieval Thought, Leuven University Press, Leuven 2004., str. 134-153, str. 134-139; usp. Jan A. Aertsen, Medieval Philosophy as Transcendental Thought: From Philip the Chancellor (ca. 1225) to Francisco Suárez, Brill, Leiden 2012., str. 15-20, doi https://doi.org/10.1163/9789004225855.

To je ključna razlika spram kantovskog pojma transcendentalnog. Naime, Kantov pojam transcendentalnog stoji nasuprot empirijskog, dok srednjovjekovni pojam transcendentalnog stoji nasuprot kategorijalnog. O tome vidi više u: Jan A. Aertsen, Medieval Philosophy and the Transcendentals: The Case of Thomas Aquinas, Brill, Leiden 1996., str. 22; usp. Cornelio Fabro, »The Transcendentality of Ens-Esse and the Ground of Metaphysics«, International Philosophical Quarterly 6 (1966) 3, str. 389-427, str. 390-417, doi: https://doi.org/10.5840/ipq1966634.

De sub. sep., cap. 11, u: Toma Akvinski, Opuscula philosophica, sv. 1, preveo Augustin Pavlović, Demetra, Zagreb 1995., str. 256. Pojam transcendens/transcendentia razvijao se tijekom povijesnog razdoblja srednjovjekovne filozofije, počevši od Filipa Kancelara (Philippus Cancellarius Parisiensis, 1160 - 1236.), koji je u djelu Summa de bono (oko 1225.) prvi sistematski izložio učenje o transcendentalima i polako zamjenjivao pojmove nomina communissima, termini generales, prima, primae intentiones, conditiones concomitantes, impressiones itd. I drugi onovremeni mislioci koriste iste nazive, ali se naziv transcendentalis prvi put pojavljuje u djelu Disputationes metaphysicae Francisca Suáre- za (1597.). O tome vidi više u: J. A. Aertsen, Medieval Philosophy as Transcendental Thought, str. 14-15. Za genezu i historijat pojma transcendentalno u srednjem vijeku vidi više u: J. A. Aertsen, Medieval Philosophy and the Transcendentals, str. 91-92; usp. J. A. Aertsen, Medieval Philosophy as Transcendental Thought, str. 17-18.

6

Usp. ST I-II, q. 29, a. 5; usp. In De hebd., u: Toma Akvinski, Opuscula philosophica, sv. 2, preveo Augustin Pavlović, Demetra, Zagreb 1996., str. 366 .

7

Usp. ST I, q. 30, a. 3.

8

Usp. ST I, q. 5, a. 2, u: Toma Akvinski, Izabrano djelo, preveli i priredili Tomo Vereš, Anto Gavrić, Nakladni zavod Globus, Zagreb 2005., str. 312; usp. In I Sent., d. 8, q. 1, a. 3; usp. De pot., q. 9, a. 7, ad 6.

9

Usp. In De Trin., q. 4, a. 1, ad 3; usp. In Meta., proem., u: T. Akvinski, Izabrano djelo, str. 76; usp. In V Meta., 1. 1, no. 1; usp. In De Trin., q. 5, a. 1, u: T. Akvinski, Izabrano djelo, str. 101; usp. In I Sent., d. 24, q. 1, a. 3.

10

In Sent., d. 8, q. 1, a. 3. Također, važan tekst o dobru jest $S T$ I, q. 5, u: T. Akvinski, Izabrano djelo, str. 310-318.

11

Usp. Jan A. Aertsen, »The Philosophical Importance of the Doctrine of the Transcendentals in Thomas Aquinas «, Revue Internationale de Philosophie 52 (1998) 2, str. 249-268, str. 250.

12

J. A. Aertsen, Medieval Philosophy and the Transcendentals, str. 261. U tom tekstu »procedura je ekstremno stroga i [on] možda predstavlja najzgusnutiji i najformalniji tekst u cjelokupnoj povijesti zapadne misli . - C. Fabro, »The Transcendentality of Ens-Esse and the Ground of Metaphysics«, str. 409. 13

Za kronologiju vidi više u: Jean-Pierre Torell, Saint Thomas Aquinas: The Person and His Work, sv. 1, The Catholic University of America Press, Washington D. C. 1996., str. 328. Osim toga, razlog je i taj što na raspolaganju imamo barem dva pouzdana prijevoda Tome Vereša i Augustina Pavlovića. Jedan koji, nažalost, nije upotrebljiv, jer nije naveden izvor, postoji u: Toma Akvinski, Dvije filozofske rasprave, preveo Vladimir Premec, 
smislu. Ukratko, ako svi pojmovi moraju biti svedeni na prvi, ${ }^{19}$ tada taj prvi mora biti dovoljno širok da obuhvati sve drugo što se može spoznati. Jedino je moguce da primum intelligibile bude ili biće ili biće mora biti svodivo na to prvo; s obzirom na to da nema ničeg na što se biće može svesti, samo biće mora biti primum intelligibile. Štoviše, pošto svaki drugi pojam mora na kraju biti sveden na bice, ono mora biti primum intelligibile:

»Otuda je neophodno da se svi pojmovi u umu stječu dodavanjem biću. $\ll^{20}$

Primarnost bića jest primarnost u poretku objašnjenja. Biće je dio objašnjenja svakog drugog pojma (jer sve što je izraženo bilo kojim pojmom prvo mora biti da bi bilo ovo ili ono), ali ono sâmo ne zahtijeva objašnjenje nekim prethodnim pojmom. ${ }^{21}$ Prema Akvinskom, svi se pojmovi daju svesti na bicee, odnosno njegov je uvid da je svim stvarima zajedničko to da naprosto jesu. ${ }^{22}$ Biće je tako prvi princip razuma; sve što razum poima posjeduje temeljno transcendentalno svojstvo, naime svojstvo da jest i svako drugo svojstvo može biti samo određeni dodatak tomu.

\section{Dodavanje biću: kategorije}

Toma Akvinski neposredno se nadovezuje na razjašnjavanje pojma bića:

»Međutim, biću se ne može nešto dodati kao strano, kao što se razlika dodaje rodu ili pripadak nositelju, jer je svaka narav po biti biće; stoga i Filozof dokazuje u III. knj. Metafizike da biće ne može biti rod $(. .$.$) . { }^{23}$

Definicije su sastavljene od roda i vrsne razlike. Vrsna razlika mora dodati rodu nešto što se ne nalazi u biti samog roda. Ako bi učestvovala u prirodi roda, razlika bi morala biti ili vrsta unutar roda ili pojedinačni član takve jedne vrste jer je rod prireciv samo vrstama ili pojedinačnostima. No tada razlika ne bi bila razlika nego vrsta ili primjerak vrste; zbog toga, razlika mora biti potpuno izvan prirode roda. Da je biće rod, ne bi postojala razlika koja bi mu se dodavala zato što nema ničeg izvan bića. Zbog toga, biće ne može biti rod, zato što, bez ikakve razlike koja bi ga kontrahirala, ne bi bilo vrste (pa ni individuuma) kojoj bi ono bilo rod. ${ }^{24}$ Akvinčeva usputna opaska da se biću ne može ništa dodati na način na koji akcidencije dodaju supstancijama počiva na istoj vrsti zaključivanja.

Aristotelovska premisa da bice nije rod, pred Tomu Akvinskoga postavlja parmenidovski problem kako objasniti mnoštvenost, ako nema ničeg izvan bića. Slijedeći Aristotelovu slavnu izreku da se »biće kaže mnogovrsno «, 25 Akvinac tvrdi da biće izražava bitak prema različitim načinima bitka. Nastavljamo citat:

»... i Filozof dokazuje u III. knj. Metafizike da biće ne može biti rod. U tom smislu se kaže da se nešto dodaje biću ukoliko to nešto izriče način samoga bića koji se samom riječju 'biće' ne izriče. To može biti na dva načina. Prvo: tako da je izrečeni način neki poseban način bića. Postoje, doista, razni stupnjevi bićevnosti prema kojima se poimaju razni načini postojanja te se prema njima poimaju razni rodovi stvari. Naime, bivstvo biću ne dodaje neku razliku koja bi označavala neku narav biću dodanu, nego se riječju 'bivstvo' izriče neki poseban način postojanja, tj. 'biće po sebi', a tako je i u drugim rodovima. Na drugi način: tako da je izrečeni način opći način koji prati svako biće, a i taj se način može uzeti dvojako: prvo, ukoliko prati svako pojedino biće u sebi; drugo: ukoliko prati jedno biće u odnosu na drugo.« (240)

Iako se biću ne može ništa dodati na način neke njemu izvanjske prirode, ipak je moguće da neki pojam može ukazivati na način bitka bića koji nije izražen samim pojmom biće. Izraz biće ima ratio (id quod habet esse), ${ }^{26}$ koji ne pre- 
cizira na koje sve načine bića mogu biti, niti precizira na koji način možemo poimati bića. Zahvaljujući toj nepreciznosti možemo konstruirati pojmove i definicije koji su različiti od izraza biće. Budući da se razlikuju i u vrsti i u rodu, supstancije i akcidencije ne mogu se uspoređivati osim utoliko što nose ime biće, što označava sličnost koja je zajednička oboma, bez negiranja ra-

Veselin Masleša, Sarajevo 1976. U ovom tekstu bit će korišten prijevod Augustina Pavlovića jer je dosljedniji i manje opisan.

14

O tome vidi više u: In I Sent., d. 8, q. 1, a. 3; usp. J. A. Aertsen, Medieval Philosophy and the Transcendentals, str. 360-415; usp. Jason A. Mitchell, »Aquinas on the Ontological and Theological Foundation of the Transcendentals«, Alpha Omega 16 (2013) 1, str. 39-78 usp. Alain Contat, »A Hypothesis About the Science of the Transcendentals as Passiones Entis according to Saint Thomas Aquinas«, Alpha Omega 17 (2014) 2, str. 213-266 usp. Brian T. Carl, »The Transcendentals and the Divine Names in Thomas Aquinas «, American Catholic Philosophical Quarterly 92 (2018) 2, str. 225-247, doi: https://doi org/10.5840/acpq2018313148. Usp. Michae M. Waddell, »Natural Theology in St. Thomas's early doctrine of Truth «, Sapientia 59 (2004), str. 5-21.

15

De ver., q. 1, a. 1, u: Toma Akvinski, Pariške rasprave Tome Akvinskoga: raspravljena $i$ kvodlibetalna pitanja, preveo Augustin Pavlović, Demetra, Zagreb 2001., str. 240.

16

Usp. In IV Meta., 1. 4, no. 604; usp. In De Trin., q. 6, a 4.

17

»Illud autem quod primo intellectus concipit quasi notissimum, et in quod conceptiones omnes resolvit, est ens.« - T. Akvinski, $\mathrm{Pa}$ riške rasprave, str. 240.

18

Usp. In De Trin., q. 6, a. 4. O tome vidi više u: J. A. Aertsen, Medieval Philosophy and the Transcendentals, str. 74-78; usp. J. A. Aertsen, Medieval Philosophy as Transcendental Thought, str. 211-214.

19

»[B]iće je apsolutno primarno u odnosu na druga [božanska imena, dobro, jedno i istinito]. Razlog je to što je biće uključeno u razumijevanje drugih, ali obrnuto nije na djelu. Jer prva stvar koja pada u razum jest biće (primum enim quod cadit in imaginatione intellectus, est ens) bez kojeg se ništa drugo ne može razumom shvatiti (...) i zato svi drugi [pojmovi] jesu na neki način uključeni u biće, na način da su ujedinjeni i nerazgovijetni, kao $\mathrm{u}$ [svom] principu (unde omnia alia includuntur quodammodo in ente unite et indistincte, sicut in principio).« - In I Sent., d. 8, q. 1, a. 3. Akvinski ponekad koristi i izraz primum intelligibile da označi biće. O tome vidi više u: De ver., q. 23, a. 1, ad 11; usp. ST I, q. 5, a. 2, u: T. Akvinski, Izabrano djelo, str. 312. Na mnogim mjestima Akvinski kaže da je biće primum cognitum. O tome vidi više u: $D E E$, proem.; usp. ST I, q. 5, a. 2, resp., u: T. Akvinski, Izabrano djelo, str. 312. Usp. SCG II, 83, u: Toma Akvinski, Suma protiv pogana, sv. 1, preveo Augustin Pavlović, Kršćanska sadašnjost, Zagreb 1993., str. 781. Za analizu značenja prvotnosti bića kod Tome Akvinskoga vidi više u: J. A. Aertsen, Medieval Philosophy and the Transcendentals, str. 159-200; usp. Brian A. Kemple, Ens Primum Cognitum in Thomas Aquinas and the Tradition, Brill, Rodopi, Leiden, Boston 2017. doi: https://doi.org/10.1163/9789004352568. Usp. Predrag Milidrag, »Biće (ens) kao maxime primum kod Tome Akvinskog«, Theoria 60 (2017) 2, str. 174-189, doi: https://doi. org/10.2298/THEO1702174M. Usp. Predrag Milidrag, Ustrojstvo stvorenog bića $u$ De enteu Tome Akvinskog, Akademska knjiga, Institut za filozofiju i društvenu teoriju, Novi Sad, Beograd 2019., pogl. 2.

20

T. Akvinski, Pariške rasprave, str. 240.

21

Usp. De ver., q. 11, a. 1 .

22

Za razliku od, primjerice, Scotusa ili Suáreza, Akvinčev pojam bića je »egzistencijalan«. Biće je ono što izstoji (bivstvuje, opstoji), a ne ono što ima neproturječnu bit: »Ens autem non dicit quidditatem sed solum actum essendi.«-In I Sent., d. 8, q. 4, a. 2, ad 2. Akvinski isto to tvrdi i na brojnim drugim mjestima. $\mathrm{O}$ tome vidi više u: In I Sent., d. 19, q. 5, a. 1; usp. In XII Meta., 1. 1, no. 2419; usp. In I Periherm., 1. 2, 1; usp. SCG I 24, \#3, u: T. Akvinski, Suma protiv pogana, sv. 1, str. 129

23

T. Akvinski, Pariške rasprave, str. 240 24 Usp. In III Meta., 1. 8, no 433.

25

Aristotel, Metafizika, IV 1003b 5, u: Aristotel, Metafizika, preveo TomislavLadan, Globus, Sveučilišna naklada Liber, Zagreb 1988., str. 76.

26

»Sicut enim ens simpliciter est quod habet esse.«-ST I-II, q. 26, a. 4. »Ens siue id quod 
zlike u modusu njihovog bitka; na taj način, supstancija i akcidencija dodaju značenje pojmu biće koji, upravo zato što se može primijeniti i na jedno i na drugo, očito ima analogno značenje. Supstancija, primjerice, izražava modus bitka po sebi, akcidencija izražava modus bitka u drugom, biti veliko izražava kvantitetu, biti pošten kvalitetu, a biti muž odnos itd. Ni u jednom slučaju nije uvedeno ništa izvanjsko samom biću kao ograničavajuća karakteristika, nego je značenje bića kontrahirano prema različitim načinima na koje bića jesu. ${ }^{27}$ Budući da est u quod est može imati različite moduse, deset najopćijih, tako dobiveni pojmovi mogu se odnositi samo na neka bića. ${ }^{28}$

\section{Dodavanje biću: transcendentali}

Druga mogućnost za izražavanje različitih modusa bitka podržava pojmove koji su prirecivi svim bićima. Ni ovdje nije moguće dodavanje biću pomoću neke izvanjske prirode. U prvom članku dvadeset prvog pitanja Raspravljenih pitanja o istini Akvinac objašnjava da postoje tri načina na koja nešto može biti dodano nečem drugom. Prvi je način dodavanje nečeg stvarnog izvan biti stvari, kada dodatak kontrahira ono čemu je dodano (kao što »bijelo« dodaje nešto »tijelu« ili »teško« »čovjeku«). Drugi način uključuje dodavanje koje ograničava i određuje, kao što to čine kategorije u odnosu na biće. Iz ranije rečenog jasno je da nijedan od ta dva načina ne odgovara onom što transcendentali dodaju biću. Za Akvinca, transcendentali dodaju biću nešto pojmovno i to je treći način dodavanja:

»Na treći način, za nešto se kaže da nečemu drugom dodaje nešto isključivo prema razumu (aliquid addere super alterum secundum rationem tantum). To je na djelu kada pojam jednog nije pojam drugog. Međutim, to ne povlači nikakvu razliku u stvarnosti nego samo u razumu, kontrahirao pridodani pojam ono čemu se dodaje ili ne. $\ll^{29}$

Dakle, riječ je o pojmovima koji će se odnositi na isto na što se odnosi i biće, ali će izražavati nešto što sam pojam biće ne izražava.

Iako su zamjenjivi i istog opsega kao i pojam bića, transcendentalni pojmovi nisu sinonimni s bićem:

»Istinito je uređenost bića, no ne kao da bi mu dodala neku narav ni kao da bi izražavala poseban način bića, nego je ona nešto što se općenito nalazi u svakom biću, a da ipak nije izraženo riječju 'biće'. «30

Bice znači id quod est ili quod habet esse. Transcendentali pak sve što jest, ako jest, označavaju s obzirom na različite moguće pojmovne aspekte koje ono što jest može imati kao biće, a koji nisu dio značenja pojma bića kao takvog. Utoliko, njihov opseg jest podudaran s opsegom pojma biće, odnose se na isto na što se odnosi i biće, ali će označavati pojmovni aspekt koji pojam biće ne označava. Primjerice, svako biće ima odnos prema nekom razumu, to je jedan od pojmovnih aspekata pod kojima je moguće razmatrati svako biće. Aspekt onog što znači biće, što znači biti, jest biti kao asimiliran u spoznajnom razumu.

U prvom članku prvog pitanja Raspravljenih pitanja o istini Toma Akvinski izlaže različite načine generaliter consequens omne ens koji se mogu oblikovati:

»U prvom slučaju to biva dvojako: nešto se, naime, o biću izriče na potvrdan način, a nešto na niječan. No nema nekog potvrdnog bezuvjetnog iskaza o svakom biću osim njegove biti, po kojoj mu se pririče bitak; i tako se ono zove 'stvar'. Stvar se razlikuje od bića u tome što riječ 'biće' potječe od aktualnosti bivstvovanja - kako kaže Avicenna na početku Metafizike - dok riječ 'stvar' izražava štostvo ili bit stvari. Nijekanje pak koje bezuvjetno prati svako biće, jest 
nepodijeljenost, a nju izriče riječju 'jedno'. Doista, ‘jedno' nije ništa drugo doli 'nepodijeljeno biće'. ${ }^{31}$

Navedena je taksonomija motivirana logičkim mogućnostima. Pojednostavljeno govoreći, postoje dvije mogućnosti: pojam može izražavati nešto pozitivno ili nešto negativno o nekom biću. Svako je stvoreno biće sačinjeno od biti i svog akta bitka. Izraz stvar govori o biću promatranom s aspekta njegove biti; stvar (res) jest biće određeno s obzirom na to da posjeduje bit, za razliku od bića koje ima aspekt usmjeren na actus essendi. ${ }^{32}$ Pojam jedno (unum) govori nešto o biću utoliko što je biće nepodijeljeno, i to je druga moguénost.

Drugi način na koji pojam može izražavati nešto generaliter consequens omne ens jest izražavanje odnosa između bića i nečega drugoga.

»Ako se pak način bića uzme na drugi način, tj. s obzirom na odnos jednoga prema drugome, to se može uzimati dvojako. Prvo: s gledišta odijeljenosti jednoga od drugoga; i to izražava riječ 'nešto', jer 'nešto' znači ne-što. Zato, kao što se biću pririče ‘jedno' ukoliko je u sebi nepodijeljeno, tako mu se pririče 'nešto' ukoliko je odijeljeno od drugih stvari. Drugo: s gledišta slaganja jednog bića s drugim, a to jamačno nije moguće, osim ako se uzme nešto što se po naravi slaže sa svakim bićem. To je duša, koja je 'na neki način sve', kako se kaže u III. knj. O duši. U duši je pak spoznajna moć i moć težnje. Prema tome, slaganje se bića s težnjom izražava riječju 'dobro', kao što se kaže na početku Etike: 'Dobro je ono čemu sve teži'. Slaganje pak bića s umom izriče riječ 'istinito'. Svaka pak spoznaja događa se upriličenjem spoznavatelja spoznatoj stvari, tako da je spomenuto upriličenje uzrok spoznaje; npr. vid spoznaje boju time što je prilagođuje spoznajnoj slici boje. $\ll^{33}$

Utoliko što je jedno, nijedna stvar nije neka druga stvar nego je odijeljena od svih drugih stvari. Na djelu je jedna vrsta negativnog odnosa koji je prireciv svakom biću: odijeljeno je od drugih stvari; to je za Tomu smisao pojma nešto (aliquid). Logički govoreći, također je moguće da ima i nekog pozitivnijeg odnosa koji je prireciv svim bićima. Da bi se ta mogućnost aktualizirala potrebno je da postoji neko biće koje je u stanju stajati u pozitivnom odnosu prema svakoj stvari. Po mišljenju Aristotela, takva je priroda duše, koja je u nekom smislu sve stvari. ${ }^{34}$ Kroz svoje moći, duša dopušta stvorevinama da budu dovedene u odnos s drugim bićima. Taj odnos duše prema drugim bićima konstituira posljednja dva transcendentala. Intelektualna moć duše odnosi se prema bićima utoliko što su ona inteligibilna; posljedični odnos adekvacije duše i stvari jest istinito (verum). Slijedeći spoznaju, voljne moći duše mogu željeti predmet. Moć želje želi savršenstvo bića djelatnika, a predmet je sagledavan pod aspektom cilja koji usavršava djelatnika. Iz toga slijedi da ukoliko

est.« - In De hebd., 2, u: T. Akvinski, Opuscula philosophica, sv. 1, str. 368 .

27

Usp. ST I, q. 5, a. 3, ad 1, u: T. Akvinski, Izabrano djelo, str. 313.

\section{8}

Usp. In VMeta., 1. 9, no. 890. Za detaljnu analizu kategorija kao modusa bitka kod Tome Akvinskoga vidi: John Tomarchio, »Aquinas's Division of Being According to Modes of Existing «, The Review of Metaphysics 54 (2001) 3, str. 585-613. Za Akvinčevo izvođenje kategorija vidi: John F. Wippel, »Thomas Aquinas's Derivation of the Aristotelian Categories (Predicaments) «, Journal of the History of Philosophy 25 (1987) 1, str. 13-34, doi: https://doi.org/10.1353/hph.1987.0002.

\section{9}

De ver., q. 21, a. 1 .

30

De ver., q. 1, a. 1, ad 4, u: T. Akvinski, Pariške rasprave, str. 244 .

31

Ibid., str. 241. Poradi terminološkog ujednačavanja s ostatkom teksta, umjesto zbiljnost stavljeno je aktualnost.

32

Usp. In III Meta., 1. 8, no 433.

33

T. Akvinski, Pariške rasprave, str. 241.

34

Usp. De anima/O duši III, 431b 20. 
biće može biti poželjno za usavršavanje drugog, utoliko je svako biće na neki način dobro (bonum).

\section{Res}

Transcendental stvar dodaje biću određenje da je ovo biće uistinu biće neke određene vrste. Stvar je biće označeno sa svoje štostvene ili bitne strane. ${ }^{35}$ Stvar i biće ipak ne označavaju nešto što bi bilo realno različito, nego označavaju isti concretum koji se zove stvar kada je promatran sa strane biti, a biće kada je promatran s obzirom na to da jest; ens je res koja est. Nadasve je važna činjenica da stvar izražava ideju o pozitivnom sadržaju i to da je riječ o nečemu unutrašnjem samoga bića:

»No nema nekog potvrdnog bezuvjetnog iskaza o svakom biću osim njegove biti, po kojoj mu se pririče bivstvovanje; i tako se ono zove stvar. «36

Kao transcendental, dakle, stvar ne ograničava biće na kategorije, nego samo bilježi određenje koje je svojstveno svakom konačnom biću, naime razdijeljenost na kategorije koja je posljedica toga što biće ima neku određenu bit; ${ }^{37}$ iz tog razloga, kada govori o podjeli bića na deset kategorija Akvinski često to povezuje sa zamjenjivošću bića i stvari. ${ }^{38}$ Stvar, dakle, nije bit stvari, nego je cijelo biće određeno sa stanovišta svoje biti; zato izraz bit stvari nije pleonazam i zato govorimo o biti čovjeka, a ne o »stvari čovjeka«.

Razlika između stvari i bića nema smisla u Aristotelovoj metafizici jer razlikovanje između forme, s jedne strane, i bitka kao principa aktualizacije, s druge, jedno je od velikih promjena koju donosi Akvinčeva metafizika spram aristotelovske. Toma Akvinski može razlikovati činjenicu da nešto jest od činjenice da je to ove ili one vrste. Upravo je to razlika između bića i stvari. ${ }^{39}$

Za stvar je karakteristično to da je riječ o jedinom transcendentalu koji nije osnovan na aktu bitka bića (actus essendi), nego na drugoj komponenti ustrojstva bića, na biti koja je realno različita od bitka. Ta činjenica svakako privlači pažnju, tim više što nijedan Akvinčev tekst, čak ni na najopćiji način, ne razjašnjava tip additio koji stvar razlikuje od bića. ${ }^{40}$ Osim toga, dok je u Komentaru Sentencija transcendental jedno bio najbliži biću, ${ }^{41} \mathrm{u}$ prvom članku prvog pitanja Raspravljenih pitanja o istini na tom mjestu nalazi se stvar. Svakako, povijesno-filozofijski razlog za to jest Avicennin utjecaj i to što on stvar navodi kao jedan od prva tri utiska u duši. ${ }^{42}$ Nadalje, treba pogledati i Akvinčev odgovor na treću primjedbu u tom članku, koja počiva na izjednačavanju quod est i ens. ${ }^{43}$ Akvinski odbacuje argument, primjećujući da je biće uzeto od bitka, dok se stvar kaže s obzirom na bit. ${ }^{44}$ Dakle, Akvinčev odgovor ovisi o razlici bića i stvari. No tu je i treći, najvažniji argument: ako su svi modi entis generaliter consequens omne ens pojmovi koji mogu i moraju biti svedeni na biće, tada samo biće možda nije modus entis generaliter consequens omne ens. Drugim riječima, ens možda nije modus bića koliko je biće sâmo. Ako je tako, onda se mora pronaći drugi pojam koji će zauzeti njegovo mjesto i kojim će se reći nešto afirmativno o svakom ens in se. Stvar je upravo takav pojam i upravo zato Toma Akvinski nije uključio stvar kao drugu alternativu u kategoriji modus entis generaliter consequens omne ens in se dicitur affirmative, nego kao jedinu ponuđenu. Tek se iz ove perspektive jasno vidi posebno mjesto koje ima biće, naime ono nije tek jedna od transcendentala, nego je prvotni transcendental (maxime primum $)^{45}$ ili, kako bi Fabro kazao, ona je »transcendentalizirajući transcendental ${ }^{4}{ }^{46}$ 


\section{Unum}

U Komentaru Boetijeva spisa $\mathrm{O}$ trojstvu, u kontekstu problema uzroka mnoštvenosti, Toma Akvinski pojam jednog kao transcendentala objašnjava na sljedeći način:

»Za [jedno] biće nemoguće je da bude odijeljeno od [drugog] bića ako je biće, jer ništa nije odijeljeno od bića osim nebića. I otud ovo biće nije odijeljeno od onog bića osim u slučaju da nije jer je u ovom biću uključena negacija onog bića. «7

Jedno je ovo biće, a nije ono biće koje je također biće, ali je biće na drugačiji način. Jedno, dakle, ne označava nedjeljivost kao takvu nego nedjeljivost bića. ${ }^{48}$ Transcendentalno jedno ne treba miješati s brojem jedan kojim mjerimo stvari prema jedinicama. Broj jedan je princip akcidentalne kategorije kvantitete i osnova za nabrajanje. Transcendentalno jedno po definiciji ne može biti ograničeno ni na jednu kategoriju. ${ }^{49}$ Jedno izražava nepodijeljenost bića u sebi samom. Stoga, jedno ne negira mnoštvenost bića, nego podjelu u samom biću. Aristotel i Averroes kažu

35

Usp. SCG I, 25, u: T. Akvinski, Suma protiv pogana, sv. 1, str. 129; usp. In IV Meta., 1. 2, no. 553; usp. In I Sent. d. 8, q. 4, a. 2, ad 2.

36

T. Akvinski, Pariške rasprave, str. 241. Osim u De ver., q. 1, a. 1, Akvinski na još dva mjesta eksplicitno govori o stvari kao transcendentalu: In I Sent., d. 2, q. 1, a. 5, ad 2 i ST I, q. 39 , a. 3 , ad 3.

37

Usp. In IV Meta., 1. 2, no. 553.

38

Usp. $S T$ I, q. 48, a. 2, ad 2; usp. $S C G$ III 8-9. 39

O pojmu stvari kod Avicenne kao izvora za Akvinčevo razumijevanje vidi više u: Jan A. Aertsen, »Avicenna's Doctrine of the Primary Notions and its Impact on Medieval Philosophy «, u: Anna Akasoy, Wim Raven (ur.), Islamic Thought in the Middle Ages: Studies in Text, Transmission and Translation, in Honour of Hans Daiber, Brill, Leiden, Boston 2008., str. 21-42, doi: https://doi. org/10.1163/ej.9789004165656.i-711. Usp. Jan A. Aertsen, »'Res' as Transcendental: Its Introduction and Significance«, u: Graziella Federici-Vescovini (ur.), Le problème des transcendantaux du XIV au XVII siècle, Librairie Philosophique Vrin, Pariz 2002., str. 140-155, str. 142-145; usp. Daniel D. De Haan, »A Mereological Construal of the Primary Notions Being and Thing in Avicenna and Aquinas«, American Catholic Philosophical Quarterly 88 (2014) 2, str. 335-360, str. 341-350, doi: https://doi.org/10.5840/ acpq20145229.

40

Za analizu odnosa stvari i bića vidi više u Jason A. Mitchell, Being And Participation.
The Method and Structure of Metaphysical Reflection according to Cornelio Fabro, Ateneo Pontificio Regina Apostolorum, Roma, str. 3-5; usp. A. Contat, »A Hypothesis About the Science of the Transcendentals«, str. 235-238.

41

In I Sent., d. 8, q. 1, a. 3.

42

Uz biće i nužno.

43

Usp. De ver., q. 1, a. 1, obj. 3, u: T. Akvinski, Pariške rasprave, str. 237.

44

»Kad se kaže: 'Bitak je različit od onoga što jest', razlikuje se aktualnost bivstvovanja od onoga čemu ta aktualnost pristaje. A riječ 'biće' uzima se od aktualnosti bivstvovanja, a ne od onoga čemu aktualnosti bivstvovanja pristaje.«-De ver., q. 1, a. 1, ad 3, u: T. Akvinski, Pariške rasprave, str. 245.

45

Usp. De pot., q. 9, a. 7, ad 6.

46

C. Fabro, »The Transcendentality of EnsEsse and the Ground of Metaphysics «, str. 420-421.

47

In De Trin., q. 4, a. 1.

48

Usp. In X Meta., 1. 4, no. 1988; usp. In IV Meta., 1. 3, no. 565.

49

O razlici između dvije vrste jedinstva vidi više u: ST I, q. 11, a. 1 ad 1; De Pot., q. 3, a. 16. ad 3. 
»... da jedno koje je zamjenjivo s bićem ne dodaje ništa pozitivno onom čemu je pridodano iz tog razloga što se za stvar ne kaže da jest jedna kroz neku dodanu uređenost, jer to bi sadržavalo beskonačan regres; pošto je i ona jedna, i sama dodana uređenost bila bi jedna po nekom drugom jedinstvu. Tako kažu da jedno obuhvaća zajedničko biće u svom pojmu i da tek dodaje pojam privacije ili izvjesnu vrstu negacije, tj. dodaje pojam nedjeljivosti. Dakle, biće i jedno jesu zamjenjivi u smislu da su ista stvar. Oni se razlikuju samo u pojmu, tj. u mjeri da jedno dodaje negaciju biću. $\ll^{50}$

Za svako složeno biće gubitak jedinstva znači i gubitak bitka i tome se sva bića odupiru zahvaljujući prirodnom dinamizmu bića k punom savršenstvu. ${ }^{51}$ Princip transcendentalnog jedinstva odražava se u principu neproturječnosti. Jer ukoliko nešto jest, ono utoliko mora biti jedno i otud ne može biti dvije odvojene stvari, a ako jesu dvije različite stvari, onda ne može biti jedna. Očito je da, ukoliko postoji, utoliko jednostavno biće bez konstitutivnih dijelova posjeduje jedinstvo na egzemplaran način. To bi impliciralo da jednostavno biće jest bitak i ništa drugo doli bitak (esse tantum) ${ }^{52}$ jer bi u suprotnom bilo biće u kompoziciji s nečim drugim. Za Akvinca, to je Bog, koji je najistinitija referenca na jedinstvo; u svakoj drugoj stvari, utoliko što je sastavljena, jedinstva ima samo zato što akt bitka dovodi bit u bitak kao jednu supstancijalnu cjelinu.

\section{Aliquid}

Iz nepodijeljenosti bića kao takvog nužno slijedi njegova odijeljenost od svega što nije ono samo. Pojam nečega izražava činjenicu da biće označava nešto jedinstveno, pojedinačno, što nije u stanju biti drugo biće, nešto »odvojeno« od svih drugih bića. Kako Akvinski kaže, nešto izražava poredak jedne stvari prema drugoj i to s obzirom na podjelu. Kao što se biće zove jedno utoliko što nije podijeljeno u sebi samom, naziva se nešto zato što je odijeljeno od drugih.

Nešto ne treba razumjeti kao pojam suprotan nihil, nego više u tehničkom smislu nekog-drugog-što, tj. prirode koja je različita od svih ostalih. Umjesto naglašavanja pomanjkanja unutrašnje podjele u biću, kao kod jednog, nešto naglašava razliku i odvojenost od svih drugih bića. Biće je drugo u odnosu na to drugo biće, za to drugo biće biće je nešto. Drugačije rečeno, nešto je rezultat razmatranja bića iz perspektive drugih bića, odnosa s njima i razlike spram njih. ${ }^{53}$ Svako je biće jedinstveno i nije neko drugo biće. Nijedno biće nije nebiće, jest po sebi, jest ono što jest, nije ono što nije i jest različito od svih drugih; čak i riječ nešto implicira »neko drugo što $(\text { quasi aliud quid })^{54} \mathrm{i}$ definiramo nešto kao biće promatrano u odnosu prema drugom kao drugom.

Aliquid je priznanje da, iako nepodijeljena u sebi, svaka konačna stvar nužno stoji u odnosu s drugim stvarima. Drugim riječima, ona mora biti nešto drugo od svakog drugog konačnog bića pošto je njen vlastiti akt bitka različit od akta bitka svake druge stvari. Ta razdioba objašnjava ne samo mnoštvenost vrsta nego i mnoštvenost pojedinačnosti unutar vrste. No to je i prepoznavanje bića kao bića jer dodaje pojmovnu razliku koja zahvaća činjenicu da se bitak pojavljuje u mnoštvu modusa.

Važno je odnosno prisustvo objašnjeno transcendentalom nešto jer nas usmjerava k odnosnim transcendentalima: istinitom i dobrom. Ti su transcendentali odnosi slaganja dinamički prisutne supstancije i duha.

\section{Verum}

Kao transcendental, istinito ukazuje na odnos bića prema duhu koji je sposoban za spoznavanje bića. Utoliko što ima sposobnost na takav način biti 
u odnosu s duhom, svako biće ima svojstvo istinitog. Posljedično, Akvinski definira istinu kao slaganje razuma i bića stvari. ${ }^{55}$ No, kako Akvinac smjesta uviđa, to pokreće sljedeće pitanje: ako je istina odnos prema razumu, mora li postojati razum da bi uopće bilo istine? Zar se ne bi za same stvari kao takve moglo reći da su istinite, neovisno o tome jesu li zahvaćene nekim razumom? Ukoliko je transcendentalno svojstvo, utoliko istinito mora biti zamjenjivo s bićem, postojale razumske stvari ili ne.

Akvinski počinje razrješavati taj problem razlikovanjem različitih smislova istine. U punom smislu, istina je ovisna o postojanju razuma:

»Treba reći kako u pogledu onih svojstava koja se mnogim stvarima pririču prvotnije i drugotnije, nije nužno da se onome koje je uzrok drugih stvari prvotnije pririče opće svojstvo negoli onome u čemu je pojam onog općeg svojstva najprije ostvaren. (...) I zato, budući da se istinito mnogim stvarima pririče prvotnije i drugotnije, nužno je da se prvotnije pririče onomu u čemu se najprije nalazi ostvaren pojam istine. $\ll^{56}$

Otud, naprosto prema značenju riječi, istinito mora biti prvo pronađeno $\mathrm{u}$ razumu jer ukazuje na odnos odgovaranja razuma i stvari. Ako su sve stvari istinite, onda nužno mora postojati odnos prema nekom razumu tako da je taj odnos koekstenzivan sa samim bićem spoznate stvari.

Čini se da određenje istine kao primjereno smještene u razum proizvodi problem jer otvara mogućnost relativizma u slučaju da je razum o kojem je riječ uvijek ljudski razum. Akvinčevo rješenje problema počiva na metafizičkoj ovisnosti stvorevina o Bogu. Utoliko što je Bog dao bitak stvorevini, odnos stvorevine prema božanskom razumu, posebno prema božanskom praktičnom razumu pomoću kojega Bog stvara, konstituira primarnu istinu za svaku supstanciju. Zbog toga Akvinac uspoređuje božanski praktični razum s razumom umjetnika jer božanski praktični razum određuje što će biti. ${ }^{57}$ Kao i umjetnik, Bog određuje istinu onoga čemu će biti dan bitak i njegovo znanje o tome ne ovisi o stvorevini. Budući da Bog konstituira sam bitak u stvaranju, istina nije samo relativna za razum nego ima istinsku objektivnu kvalitetu, usprkos nenužnosti ljudske spoznaje:

»Dakle, istina najprije i u pravom smislu postoji u božanskom umu, a u ljudskom, doduše, u pravom smislu, ali drugotno, dok u stvarima u nepravom smislu i drugotno jer je u njima samo u

50

»Dicunt ergo, quod unum quod convertitur cum ente, nihil positive addit ad id cui adiungitur, eo quod res non dicitur esse una per aliquam dispositionem additam: quia sic esset abire in infinitum, si ista etiam dispositio, cum sit una, per aliquam aliam unitatem una esset. Unde dicunt, quod unum claudit in intellectu suo ens commune, et addit rationem privationis vel negationis cuiusdam super ens, idest indivisionis. Unde ens et unum convertuntur, sicut quae sunt idem re, et differunt per rationem tantum, secundum quod unum addit negationem super ens.« - In I Sent., d. 24, q. 1, a. 3. Vidi i: $S T$ I, q. 11, a. 1; In IV Meta., 1. 2, no. 560 .

51

»Na isti način na koji stvar posjeduje bitak, posjeduje i jednotu; stoga se svaka stvar prema mogućnosti opire dijeljenju, kako ne bi time smjerala k nebitku.« - SCG I, 42, \#14, u: T. Akvinski, Suma protiv pogana, sv. 1, str. 183.
52

Usp. $D E E$ IV.

53

$\mathrm{O}$ vezi između aliquid i multitudo vidi više u: De pot., q. 7, a. 9.

54

De ver., q. 1, a. 1.

55

ST I, q. 16, a. 2, u: Toma Akvinski, Izbor iz djela, sv. 1, preveli Veljko Gortan i dr., Naprijed, Zagreb 1990., str. 213.

56

De ver., q. 1, a. 2, u: T. Akvinski, Pariške rasprave, str. 247-248.

57

Ibid 
odnosu na jednu od spomenutih dviju istina. (...) [Istina stvari] se spram božanskog uma odnosi kao spram uzroka, a spram ljudskog na neki način kao spram učinka jer um znanje prima od stvari. $\ll^{58}$

Otud, primarna referenca istine jest na božanski praktični razum jednostavno jer, kao izvor sveg bitka, mjeri bitak svake supstancije.

Svako biće ima inherentnu inteligibilnost zato što ima bitak, zato što je entitet koji je stvorio Bog i koji je istinit u božanskom praktičnom razumu. Budući da je aktualno, biće može aktualizirati receptivnost ljudskog razuma i tako biti istinito u ljudskoj spoznaji. Otud, govoreći slobodnije, bića su predmeti duha jer imaju bitak, ali su istinita zato što imaju bitak od Boga. Posljedica toga jest to da što je veći stupanj bitka ili aktualnosti u nečemu, za to se može reći da je istinitije. ${ }^{59}$ Otud, čisti akt bitka (ipsum esse subsistens), Bog, nije samo nešto istinito nego je istina sama; stvorevine, kao ograničeni modusi bitka posjeduju ograničenu istinu. ${ }^{60}$

\section{Bonum}

Budući da su transcendentali tek pojmovni dodatci bitku, i pri određivanju dobrog dominikanski se učitelj oslanja na biće. Posljedično, dobro poistovjećuje s činjenicom da kao aktualizacija potencijalnosti biće jest savršenstvo, ${ }^{61}$ a dobro je potpuno aktualno biće:

»Dobro i biće stvarno su istovjetni, a razlikuju se samo pojmovno. (...) Pojam dobra sastoji se, naime, u tome da je nešto predmet težnje. Stoga Filozof u I. knj. Etike kaže da je dobro ono 'čemu sve teži'. No očito je da je svaka stvar predmet težnje ukoliko je savršena jer sve teži za svojim savršenstvom. Stoga je očito da je neka stvar dobra utoliko ukoliko je biće: bivstvovanje je, naime, aktualnost svake stvari, kao što je očito iz prethodnoga. Iz toga je jasno da su dobro i biće stvarno istovjetni, ali dobro izriče pojam predmeta težnje, što biće ne kazuje.« ${ }^{62}$

To može predstavljati problem u vezi s transcendentalnom prirodom dobra. Ako dobro bića jest njegovo savršenstvo i sposobnost da usavršava druge te da tako bude cilj kojem druge stvorevine teže, kako onda ono može biti transcendentalno? Nije li pomanjkanje savršenstva u stvorevinama očigledno? Drugim riječima, kako Toma Akvinski prilagođuje augustinovsko učenje da su sva bića dobra?

Za Akvinskoga dobro je savršenstvo bića. No postoje dvije vrste dobrog: transcendentalno dobro supstancijalnog bića koje ima svaki entitet i akcidentalna kvaliteta individualnog savršenstva po kojem neke supstancije usavršavaju potencijalnost svoje prirode (u čovjeku je to moralna dobrota). ${ }^{63}$ Osnovna razlika jest između jednostavnog bića, činjenice da supstancija jest, i savršenstva tog bića kroz operacije svojstvene toj supstanciji. I jedno i drugo jest biće te moramo napraviti razliku. Biće se najsvojstvenije odnosi na supstancijalno biće; akcidencije su bića samo u uvjetnom smislu zato što su modusi bitka koji ovise o supstanciji za svoje postojanje. Otud, možemo reći da je prvi akt koji konstituira supstancijalno biće naprosto biće. No s obzirom na to da dobro ima karakteristiku cilja ili savršenstva, a supstancijalno biće ima potencijalnost s obzirom na cilj, ta prva aktualnost supstancijalnog bića jest dobra samo u određenom smislu. S druge strane, s obzirom na to da stupanj savršenstva supstancije jest kvalitativna akcidencija te supstancije, bitak tih usavršujućih akcidencija jest ovisan modus bitka i tako biće u određenom smislu. Ipak, ta usavršujuća aktivnost, kao krajnje savršenstvo supstancije jest dobro naprosto:

»Dvojaka je savršenost, tj. prva i druga. Prva je savršenost forma svake pojedine stvari po kojoj stvar ima bitak, pa otuda stvar, dok traje, nije nje lišena. Druga je savršenost djelovanje, koje 
je svrha stvari ili ono čime se dolazi k svrsi. Iz prve savršenosti pak proizlazi obilježje istinitog u stvarima. Naime, po tome što stvar ima formu, oponaša umjetničku zamisao božanskog uma i stvara u duši spoznaju o sebi. Ali iz druge savršenosti u njoj slijedi obilježje dobrote, koja proizlazi iz svrhe. $\ll^{64}$

Biti supstancija traži nešto više od pukog bitka, traži da supstancija aktualizira potencijale kroz sebi svojstvene operacije. To je dobro koje je osnova za moralno ocjenjivanje, nasuprot istinski transcendentalnom dobru koje se primjenjuje na sva bića jednako na temelju njihovog bitka:

»Stvar se zove dobra i od svog akta bitka i od nekog pridodanog svojstva ili stanja. Tako se za čovjeka kaže da je dobar i kao postojeći i po tome što je pravedan i krepostan ili predodređen za blaženstvo. Po prvom dobrom biće je zamjenjivo s dobrim i obrnuto, ali po drugom, dobro je segment bića. $\ll^{65}$

\section{Glavna svojstva: cjelovitost, inkluzivnost i poredak}

Prvi članak prvog pitanja Raspravljenih pitanja o istini transcendentalne pojmove određuje na sljedeći način: biće je prvotni transcendental, stvar izražava određenje bića iz aspekta njegove štostvenosti, jedno izražava određenje bića s obzirom na njegovu unutrašnju nepodijeljenost, nešto dodaje biću pojam odijeljenosti od drugih bića, istinito dodaje pojam odnosa prema razumu (slaganje sa spoznajnom moći ljudske duše), a dobro prema volji (slaganje s volitivnom moći ljudske duše).

Biće je, recimo tako, »nulti« transcendentalni pojam iz kojeg se izvode svi ostali i to metodom additio sine contractione, dodavanjem pojmu bića značenja kojim se osnovno značenje tog pojma ne kontrahira na značenje nekog pojedinačnog bića. Dok je transkategorijalnost najočitija karakteristika transcendentala, njihova bitna funkcija u Akvinčevoj misli jest otkrivanje bogatstva onoga što znači biti biće, izražavajući moduse bitka koji pripadaju svakom biću, a koji nisu izraženi samom riječju biće ${ }^{66}$

58

De ver., q. 1, a. 4, u: T. Akvinski, Pariške ra sprave, str. 257. O tome vidi više u: A. Contat, »A Hypothesis About the Science of the Transcendentals«, str. 228-234.

59

Često se previđa da Akvinčevo esse ima implicitnu kvantitativnu dimenziju, da dopušta više i manje (što, primjerice, existentia ne dopušta). Naravno, riječ je o novoplatonističkom nasljeđu koje je stiglo preko Pseudo-Dionizija i Knjige o uzrocima. Za više o analizi toga mjesta kod Tome Akvinskoga vidi: John Nijenhuis, »'To Be' or 'To Exist': That is the Question«, Thomist: A Speculative Quarterly Review 50 (1986) 3, str. 353-394, doi: https:// doi.org/10.1353/tho.1986.0018. Za utjecaj novoplatonizma vidi: Fran O'Rourke, PseudoDionysius and the Metaphysics of Aquinas, Brill, Leiden 1992., str. 174-180.

60

Usp. SCG III, 51, u: Toma Akvinski, Suma protiv pogana, sv. 2, preveo Augustin Pavlović, Kršćanska sadašnjost, Zagreb 1994., str. 215.
61 Usp. De pot., q. 7, a. 2, ad 9.

62 ST I, q. 5, a. 1, resp., u: Akvinski, Izabrano djelo, str. 310-311.

63

Usp. De pot., q. 1, a. 1.

64

De ver., q. 1, a. 10, u: T. Akvinski, Pariške rasprave, str. 293 (umjesto oblikovnica stavljeno je forma).

65

De ver., q. 21, a. 2, ad 6.

66

»Aristotelova tvrdnja [da biće nije rod], koju je prihvatio Porfirije u djelu Isagoge, jest po karakteru čisto negativna i moderni se tumači slažu s tim zaključkom. Prema Pierreu Aubenqueu, teza da biće nije rod izražava da je univerzalnost bića kategorijalno prazna i da ništa ne doprinosi definiciji koja ukazuje što nešto jest. 'Biće' je znak siromaštva, ono nije čak ni rod. Srednjovjekovni mislioci, među- 
Kategorijalni pojam odnosi se isključivo na posebnu vrstu bića te je bjelodano da kategorije nisu identične s bićem, nego su prije međusobno isključivi modusi bića: ma što da je supstancija nije akcidencija, kvantiteta nije kvaliteta ni odnos. S druge strane, transcendentalni pojmovi izražavaju neke aspekte bića kao bića koji pripadaju svim stvarima. Dosadašnje analize omogućavaju nam da izdvojimo neke uvjete koje neki pojam mora zadovoljiti da bi mogao biti transcendental.

Prvo, transcendentali moraju dodavati nešto pojmovno (additio rationis) biću. Oni su drugačiji načini razmatranja bića, aspekti koji nisu eksplicitno sadržani u samom pojmu bića (id quod est) ni u drugim transcendentalima.

Nadalje, transcendental mora biti zamjenjiv s bićem. Biće je pojam najširega opsega jer ništa ne postoji ako nije. Transcendentalna svojstva bića kao takvog moraju imati istu apsolutnu i univerzalnu ekstenziju kakvu ima biće; Toma Akvinski eksplicitno spominje unum, verum, bonum i res kao zamjenjive s bicem, convertuntur ${ }^{67}$ Budući da nijedno transcendentalno svojstvo nije kontrakcija bića, nego se odnosi na svojstva koja prate biće kao biće, ta su svojstva zamjenjiva ne samo s bićem nego i međusobno. ${ }^{68}$

Zamjenjivost vodi do treće važne osobine jer govori o logičkoj prirodi izvođenja transcendentala: transcendentali nisu slučajno pobrojani u prvom članku prvog pitanja Raspravljenih pitanja o istini, nego kod njih postoji unutrašnje jedinstvo i poredak.

Prvi članak prvog pitanja Raspravljenih pitanja o istini središnji je tekst za Akvinčevo učenje o transcendentalima zato što izvodi poredak tih pojmova iz njihove primarne crte: izražavanje općih modusa bitka. Da je riječ o njihovoj glavnoj osobini jasno je, prije svega, iz Akvinčeve potrebe da razlikuje transcendentale od ostalih pojmova koji izražavaju samo specijalne moduse bitka. Transcendentali su identični, zamjenjivi i koekstenzivni s bićem u stvarnosti zato što izražavaju »opći način koji prati svako biće«. Slično, zato što izražavaju modus samog bića koji nije izražen imenom biće, transcendentali ne samo da pretpostavljaju i uključuju biće nego mu i dodaju značenje te su, posljedično, različiti od njega:

$»[\mathrm{~N}] \mathrm{ije}$ beskorisno ponavljanje reći dobro biće (non nugatorie dicatur ens bonum). ${ }^{69}$

Dodavanje biću ne kontrahira biće ni na jednu određenu vrstu bića, zato što takvi pojmovi kao što su jedno, dobro ili istinito transcendiraju kategorije, baš kao što to čini i samo biće.

Ukratko, tri obilježja transcendentala prema stvarnosti (zamjenjivost, identitet i koekstenzivnost) i tri obilježja prema značenju (uključenost bića, razlikovanje od bića i međusobno razlikovanje te poredak), slijede iz njihovog glavnog obilježja, izražavanja općih modusa bitka. Svaki od transcendentala koje Toma Akvinski navodi nakon bića izražava nešto što nije izraženo samim značenjem bića, na takav način da svaki idući transcendentalni pojam pretpostavlja prethodne.

Transcendentali ne samo da dodaju biću neko značenje nego to čine i u odnosu na sve transcendentalne pojmove koji prethode. Očito je da u prvom članku prvog pitanja Raspravljenih pitanja o istini ono što čini da transcendental bude bliže biću jest koliko to čini direktno: modus koji slijedi biće kao biće bliži je biću od onog koji slijedi iz odnosa bića prema drugom, a pozitivan modus bića kao bića bliži je od negativnog. To se može vidjeti iz toga što je za Akvinskoga stvar sadržana u samom određenju bića, kao onog što jest: 
»[J]er biće nije ništa drugo do ono što jest. Otud, biće je razumijevano tako da označava i stvar, kao kada kažem ono što, i egzistenciju, kao kada kažem jest. « ${ }^{70}$

Stvar zato ima mjesto odmah uz biće, a prije jednog, jer je jedini transcendental koja počiva na komponenti samog bića: dok biće počiva na egzistencijalnoj komponenti, osnova je stvari njegova štostvena komponenta. Sljedeći je modus negativno određenje bića kao takvog, tj. jedno, čime se naglašava da, iako je zasnovano na realnoj kompoziciji bitka i biti, biće jest u sebi nerazdijeljeno. Nešto je »negativni« odnosni parnjak jednog; Toma Akvinski čak određuje jedno kao ono što je nepodijeljeno u sebi i odijeljeno od drugoga $;^{71}$ osim toga, smisao jednog i nečeg čini ovisnim o stvari jer dodaje da se jedna stvorevina razlikuje od druge po biti. ${ }^{72}$ Bića se, dakle, razlikuju ne po tome da jesu nego po tome kako/što jesu, po svojoj štostvenoj komponenti. Na kraju, dolaze transcendentali koje izražavaju odnose bića prema razumu i volji. Istinito je prije dobrog zato što je bliže povezano s bićem jer se odnosi prema biću jednostavno i neposredno, dok dobro slijedi biće ako je ono na neki način savršeno, ali i zbog toga što spoznaja prirodno prethodi težnji. ${ }^{73}$

U trećem članku dvadeset i prvog pitanja Raspravljenih pitanja o istini Akvinski to pokazuje na primjeru odnosa dobrog i istinitog:

»Ukoliko su istinito i dobro promatrani u sebi samima, istinito po značenju prethodi dobrom (sic verum est prius bono secundum rationem) zato što istinito usavršava nešto specifično, dok dobro usavršava ne samo specifično nego i s obzirom na bitak koji stvar ima u stvarnosti. Otud, karakter dobrog (ratio boni) uključuje više od istinitog i konstituiran je vrstom dodavanja karakteru istinitog. Otud, dobro pretpostavlja istinito, ali istinito nadalje pretpostavlja jedno s obzirom na to da je pojam istine dovršen obuhvaćanjem od razuma, a stvar je pojmljiva utoliko što je jedno; jer tkogod ne razumije jedinstvo ne razumije ništa, kako kaže Filozof. Posljedično, ako su promatrana po sebi, onda je poredak transcendentalnih imena sljedeći: nakon bića dolazi jedno, nakon jednog dolazi istinito, a nakon istinitog dolazi dobro. $\ll^{74}$

tim, preokrenuli su negativnu tvrdnju biće nije rod u pozitivnu: biće je transcendens. Srednjovjekovna reformulacija znak je pozitivnijeg tumačenja semantičke vrijednosti bića: ne može mu se dodati nikakva razlika, biće je znak bogatstva jer uključuje sve razlike.« - J. A. Aertsen, Medieval Philosophy as Transcendental Thought, str. 61. Biće, dakle, kaže premnogo zato što kaže sve, ali zato što kaže sve bez određivanja, ono uopće ništa ne kazuje.

67

Osim De ver., q. 1, a. 1, o tome vidi više i u: $S T$ I, q. 11, a. 2; I, q. 17, a. 4; 1; SCG III 8-9, u: T. Akvinski, Suma protiv pogana, sv. 2 , str. 29.

68

Usp. J. A. Aertsen, Medieval Philosophy and the Transcendentals, str. 31.

69

De ver., 21, a. 1. Usp. De ver., q. 1, a. 1, ad 4, u: T. Akvinski, Izabrano djelo, str. 244. »Iako su zamjenjivi, transcendentalni izrazi nisu zato sinonimi, jer sinonimi označavaju istu stvar prema istom ratio. (...) Stalno iznova mislioci u XIII. stoljeću naglašavaju da nije nugatio, nije beskorisno ponavljanje istog reći biće je jedno, dobro $\mathrm{i}$ istinito.« - J. A. Aertsen, Medieval Philosophy and the Transcendentals, str. 97. Usp. Michael Tavuzzi, »Aquinas on the Operation of Additio«, The New Scholasticism 62 (1988) 3, str. 297-318, str. 315-316, doi: https://doi.org/10.5840/ newscholas198862314.

70

»[Q]uia 'ens' nichil est aliud quam 'quod est', et sic uidetur <et> rem significare, per hoc quod dico <'quod', et esse, per hoc quod dico> 'est'. «In I Perih., 5, 20.

71

In I Sent., d. 19, q. 4, a. 1, ad 2.

72

»Cum enim unum sit quod est indivisum in se et divisum ab aliis, unumquodque autem creatum per essentiam suam distinguatur $a b$ aliis.« - Ibid.

73

Usp. ST I, q. 16, a. 4, ad 2.

74

De ver., q. 21, a. 3. Akvinski u trećem članku dvadeset i prvog pitanja izostavlja dva transcendentala spomenuta u prvom članku prvog pitanja (stvar i nešto). Povjesničari filozofije 
Značenje dobrog, dakle, uključuje i pretpostavlja značenje istinitog: istina prethodi dobrom jer istinito usavršava nešto prema vrsti, dok dobro usavršava i prema vrsti i prema bitku koji ima u stvarnosti. Iako su neposredno zamjenjivi s bićem, nijedan transcendental ne dodaje značenje biću neovisno o onima koji mu prethode, nego svoje značenje gradi na njima i obuhvaća ih vlastitim značenjem: dobro dodaje istinitom zato što njegov način usavršavanja uključuje način na koji usavršava istina, dok istinito dodaje jednom zato što ništa nije moguće spoznati ako nije jedno, a kako je pokazano, ništa nije jedno ni nešto ako nije stvar, dok nešto jest stvar samo ako jest.

Bez obzira na to namjeravao li je izložiti učenje o transcendentalnim pojmovi$\mathrm{ma}^{75}$ ili ih je analizirao da bi ispitao prirodu istine, ${ }^{76}$ prvi članak prvog pitanja Raspravljenih pitanja o istini ostaje središnjim tekstom za Akvinčevo razumijevanje transcendentala jer je jedino mjesto gdje su ti pojmovi sistematski razmotreni i gdje su svi na određen način izvedeni ${ }^{77} \mathrm{~s}$ obzirom na mogućnosti pojmovnog dodavanja biću: biću se na taj način nešto može dodati negativno ili mu se može dodati neki odnos. ${ }^{78}$ To upućuje na zaključak da je možda riječ o spisku barem najvažnijih transcendentalnih pojmova. ${ }^{79}$ 


\title{
Predrag Milidrag
}

\section{Thomas Aquinas on the Transcendentals in De veritate, $q .1$, a. 1}

\begin{abstract}
The article analyses Aquinas's derivation of the transcendental notions in the first article of the first question of The Disputed Questions on the Truth. After showing the way for adding to ens, there is a detailed analysis of the notions res, unum, aliquid, verum and bonum. The analysis of the notion of thing has shown the special position of ens as a transcendental, namely as a primary, "transcendentalizing" transcendental (Cornelio Fabro). In the context of verum and bonum, it is pointed to the difference between the true and the good as the transcendental notions and the true and the good in a cognitive and ethical sense. In the end, the three features of transcendentals in Aquinas concerning reality (they are convertible, identical and coextensive with ens) were singled out, as well as the three features concerning their meaning (they include the ens, they differ from ens and each other, and the order among them).
\end{abstract}

\section{Key words}

Thomas Aquinas, transcendentals, one, thing, being, true, good, other, metaphysics, scholastics

slažu se da je riječ o različitim kontekstima koji to određuju te da su stvar i nešto uklopivi u shemu dvadeset i prvog pitanja. O tome vidi više u: Michael J. Rubin, »The Places of 'Thing' and 'Something' in Aquinas's Order of the Transcendentals «, The Thomist: A Speculative Quarterly Review 81 (2017) 3, str. 395-436, doi: https://doi.org/10.1353/ tho.2017.0029. O sličnostima i razlikama između izvođenja transcendentala u prvom i dvadeset prvom pitanju vidi u: J. A. Aertsen, Medieval Philosophy and the Transcendentals, str. 101-103.

75

Usp. J. A. Aertsen, Medieval Philosophy as Transcendental Thought, str. 165.

76

Usp. Michael M. Waddell, »Truth or Transcendentals: What was St. Thomas's Intention at De Veritate 1.1? «, The Thomist: A Speculative Quarterly Review 67 (2003) 2, str. 197219, str. 215. doi: https://doi.org/10.1353/ tho.2003.0024.

77

Kada su kategorije u pitanju Toma Akvinski pokušava isto. Usp. J. F. Wippel, »Thomas Aquinas's Derivation of the Aristotelian Categories «, str. 213-226; usp. John F. Wippel, The Metaphysical Thought of Thomas Aqui- nas: From Finite Being to Uncreated Being, The Catholic University of America Press, Washington, D.C. 2000., str. 213-226.

78

Usp. De ver., q. 1, a. 1; q. 21, a. 1.

79

Osim citiranog mjesta iz djela De ver., q. 21, Akvinski o transcendentalima govori, primjerice, u devetom članku devedeset trećeg pitanja prvog dijela Sume teologije. Govori o tri trancendentala (unum, verum, bonum), s referencom ne na biće nego na njihovu univerzalnost. Također, osim dobrog i zlo ( $m a$ lum) spominje se kao neka vrsta trancendentala, iako ne kao zamjenjiv s bićem (usp. In II Sent., d. 34, q. 1, a. 2, ad 1). Nadalje, u važnim tekstovima pojavljuje se mnoštvo (multitudo) (usp. SCG I, 50; usp. In Meta., proem.) razumijevano kao nedjeljivost i koje je zajedno $s$ jednim transkategorijalno (usp. ST I, q. 30, a. 3 , ad 1 , ad 2; q. 50, a. 3, ad 1). Pažnju svakako privlači i izostanak lijepog (pulchrum) sa spiska, iako drugdje dominikanski učitelj kaže da nema ničeg što ne učestvuje u lijepom i dobrom (usp. De ver., q. 22, a. 1, ad 12) ili da se lijepo od dobrog razlikuje samo pojmovno (usp. ST I-II, q. 27, a. 1, ad 3). O tome vidi više u: J. A. Aertsen, Medieval Philosophy and the Transcendentals, str. 335-359. 